\title{
Future Trends in the B.C. Forest Industry: Moving Beyond the Myths ${ }^{1}$
}

by

W.G. (Gerry) Burch, RPF²

\section{Introduction}

Being an Alumnus is a wonderful thing. It allows you to look back and pontificate about everything. For the first time, you feel wiser than your teachers by virtue of the fact that you're slogging it out in the so-called real world while they're still in the old ivory tower. As an Alumnus, I want to warn those of you who are about to join our illustrious ranks that you will soon embark upon a 25-year-process of looking back on your days here at the university. You will complain, and your complaints will follow a set pattern.

In the first five years after graduation, you will say that you should have been taught more practical techniques. In the next five years, you will say you should have been given more basic theory. Ten to 15 years after your graduation you will inform the Faculty that you should have been taught more about administration, how to write a report, labour relations and communication with politicians and the media. In the subsequent five years you will condemn the failure of your professors to put the forestry profession in its larger historical, social and economic context. After the 20th year, you will insist you should have been given broader orientation to all knowledge - scientific and human. Some time after that you will stop bothering your old professors and stop giving advice. You will conclude that the university has deteriorated so badly since you left, that it is beyond hope!

Forestry was an exciting profession when I was starting out forty years ago. And that is one thing at least that hasn't changed. In fact, it's more exciting today than ever before.

No doubt the invitation to give this lecture was inspired, at least in part, by the notion that after 40 years in the business, I should be able to convey to you the collected wit and wisdom of one Gerry Burch, RPF. You know the type of thing - a list of what worked, what didn't, and why. A pep talk as I pass on the planting bag to avoid my mistakes and build upon my successes. But after thinking about it for awhile I decided that I would find it difficult to do. I would find it difficult because the older I get the more I have come to question the doctrine that "age brings wisdom". The young people of today will probably see more change than Methuselah saw in his 969 year lifetime.

I've certainly seen a lot of change in the forestry business. And l'd be very surprised if the foresters "out of the gate" today don't see as much - if not more - changes over the course of their careers. I've watched this province go from cutting 20

\footnotetext{
Burgess-Lane Lecture. February 26, 1987. Faculty of Forestry. University of British Columbia

2Vice-President, Timberlands \& Forestry, British Columbia Forest Products Limited.
}

million $\mathrm{m}^{3}$ a year to 75 million. From planting 6 million seedlings a year to being well on our way to 200 million. From doing mapping and inventory cruises on foot to using infrared photos and computers. From handling the drunks in the local beer parlours a shovel and pointing them in the direction of a forest fire to satellite detection and specialized initial attack crews rapelling out of planes.

The first thing I want to do today is review some of the changes I've seen - take a look at where we've been, where we are now and where we seem to be heading in the state of forestry in B.C. And then I want to tell you about an incredible imaginary phone call I received last Sunday from Victoria. But first: the Gerry Burch version of the state of the forestry in B.C. - where have we come from, where are we now and, if we keep on as we are now, where will we end up?

As I said earlier, change has been the norm since I entered the forestry business. But rather than simply run through a list of the changes I've seen, l'd like to try to put those changes in perspective - look at how they relate to what has been going on in society as a whole during the last four decades. In fact, the need to consider forestry in its larger context is going to be a bit of a recurring theme in what I have to say today. If there's one enduring lesson that those of us in the forestry profession can draw from the difficulties on the forest scene in this province during the past few years it is that modern forestry is not some abstract science floating around out there in the ether - disconnected to the emotions and events that shape and fashion the rest of our society.

I'll admit there was a time when the forest constituency could isolate itself from what was happening elsewhere in society. There was a time when we could afford the luxury of focussing all our attention and energy on the technical tasks at hand - such as building roads, harvesting trees, managing the forests, operating mills and selling products. But those days are long gone.

Forestry does not operate in a vacuum. We live in a complex society that has undergone a major shift in attitudes, and values, in areas that can have a "make-it or break-it" impact on the practice of forestry. If the forest community is to assume a leadership role in resolving some of the resource questions now confronting British Columbia the members of that community must be capable of recognizing the diverse needs and values of the society that we live in. And sometimes that is pretty hard for groups - like us - to do. We're trained to be experts - to have specialized knowledge - in one area. We're trained to conceptualize problems scientifically in "cut and dried" terms. And believe me, it's frustrating as hell to watch science and reason take a back seat to politics and 
emotion. But that's the way it is sometimes. And like it or lump it, we've got to deal with that fact.

I made a joke earlier about recent graduates being critical of their former teachers for not providing broader exposure to all knowledge, scientific and human. But in a way it's no joke. More than ever before, those of us in forestry need to have a keen appreciation of the larger historical, social and economic contexts in which we operate. We feel that what we're doing is highly relevant - even critical - to the rest of society. The problem is: not everybody else does! We've got some convincing to do. To be persuasive, we've got to be smart enough to prevent ourselves from becoming victims of our own subjectivity. We've got to constantly remind ourselves how our goals and objectives relate to the total picture.

\section{But enough preaching! Where have we come from?}

I got my start in this business in 1948. I had a choice of going to work for BCFP as a cruiser at $\$ 250 /$ month or being a mapper for the Forest Service at a lower salary. Well, I liked it at BCFP so I decided to stay there - but only for about forty years.

My career began at a pretty important time in the history of forestry in this province. Two years earlier Chief Justice Gordon Sloan - aided and abetted a great deal by Dr. Dick Orchard, Chief Forester of the day - had changed the philosophy of timber supply management in this province by translating sustained yield from a theoretical concept to a practical working tool. Forestry in this province had been born - but it was just a baby.

\section{The 50's - Protection}

Every generation tends to feel like its on the leading edge of change and the 50's were no exception. They were an exciting time - a time of tremendous change and anticipation - in forestry and throughout society. Like me, the typical young person of the day entering the working world would have been: One: male. Two: sure of his beliefs and values - one of which was that women worked best in a non-stressful, noncompetitive climate ... like a kitchen, for example. And Three: confident of his future as being successful at work. He likely also saw himself as married to a supportive spouse, and as the wise, unflappable parent of 2.5 kids. Someone like, say, Ward Cleaver.

The world at large was getting used to a peace constantly threatened by the Cold War. The western economy was entering a period of dramatic growth and prosperity. Scientific principles were being applied not just to the assembly line, or the loading dock, but to the process of management itself.

The business of North America truly was business, and exciting business at that. Everybody was looking for a house in the suburbs. We were all purchasing a new gizmo called a TV set and watching the weekly adventures of Lucy and Ricky Ricardo and Fred and Ethel Mertz. A cup of coffee cost a dime. On the Canadian political scene, the St. Laurent Liberals lost to the Diefenbaker Conservatives in one of the most closely contested elections on record. A year later, Diefenbaker swept to power with his "vision of the north".

Meanwhile, for those of us in forestry in the 50's "Protection" was the overriding challenge. If we couldn't stop those darned fires, effective forest management would remain an impossible goal. It was in the 50's that slash burning instructions were first given on the north coast and on the west coast of the Island.
The second Sloan Commission report was released in '57. It basically supported the recommendations of the first report. At last Forest Management Licenses were being granted and for the first time, industry was being accepted as a partner in forest management. Senior Forest Service foresters were leaving the Ministry to join the new large companies as Chief Foresters.

The industry itself was concentrated on the coast, and was basically a mixture of small to medium-sized companies, mainly owning sawmills - a lot of the interior plants were "bush mills" and there were a few of those "new product" mills called plywood plants.

The provincial production in 1955 was around 30 million $\mathrm{m}^{3}$. The utilization standard on the coast was to a 12-inch top. There wasn't much planting going on. About 7 million seedlings in 1955 and most of these were Douglas-fir. But we were beginning to experiment with seedlings of other species and I remember being pretty excited when the first cone collection of any size was carried out in 1959. By the end of the 50 's, many North Americans figured things had changed a lot - mainly for the better - and most of us felt pretty confident about where we seemed to be heading.

Figure 1. The 50's - "Protection"

- Fire prevention/slash burning

- Sloan II

- TFLs/Forest Management Licenses

- Sawmilling/coast

- Production - 30 million cubic metres Utilisation: 12 inch top (coast)

- 7 million seedlings

\section{The 60's - Utilization}

\section{And then came the 60's.}

Well, it turned out most of us didn't even know the meaning of the word change. Fortunately, there was another generation that was just aching to tell everyone what it was all about. And they did ... in no uncertain terms.

The decade began with one of the most traumatic events in western social history - the assassination of John Kennedy. And the trauma continued. The name of a small, hitherto unknown South East Asian country, became a household word as the bloody guerrilla war in Vietnam spilled over into the living rooms and college campuses of North America. Hems went up and hair went down. The Smothers Brothers and Laugh-In were the big hits on TV. Marijuana plants could be seen growing in the odd suburban garden. A little known writer named Rachel Carson wrote a book about the environment called SILENT SPRING. A cup of coffee cost 15 cents. A bow-tied Lester Pearson took over when the Tories self-destructed. When he stepped down, Trudeaumania became the rage.

And on the forestry front? The emphasis was shifting from "protection" to better utilization of our stands. Diameter limits dropped to 8 inches. The pressure was on for lower stumps, abandoning long butting, and the need to remove "slab" cedar and "chip" logs. 
B.C.'s most famous cruiser - Eustace Smith - died in 1964. Eustace Smith knew the woods of this province better than any man during his lifetime. And we owe him a lot. If it weren't for the big " $S$ " he used to mark on trees near the old survey posts, we cruisers would still be out there trying to find old claim boundaries.

Three pulp mills had been started up on the coast, basically to utilize residues. The coastal companies were getting larger. Tenures were being consolidated and TFLs were in disfavour because of sales to larger companies and charges of corruption on the granting of tenures. Long-term -15 year timber sales were becoming common. A new form of tenure Pulpwood Harvesting Areas - was paving the way for pulp mills in the interior. Sustained Yield Units (SYU) were established and the quota system was born.

\section{By the mid-sixties the AAC had reached 45 million $\mathrm{m}^{3}$.}

At the beginning of the decade, less than $10 \%$ of logged areas were being replanted. By 1965 , planting increased to 17.8 million seedlings - but virtually all of this was occurring on the coast. Fir was still the primary species for restocking logged lands. No intensive forestry projects were being conducted but trials in fertilization, spacing and genetics were started.

In many respects, it's hard to imagine a decade of more turbulence or change than the 60's - in forestry and elsewhere. Much of the early 70's were spent just licking the wounds. But it would be a mistake to assume that the 70's didn't qualify in their own right as a period of significant change.

The seed planted by Rachel Carson in the 60's exploded into a movement that changed some of the fundamental values in our society about the environment. On the political scene, there was Watergate. The relationship between the media and politicians, and between business and the community at large, became infinitely more complex. Battlelines were being drawn. Archie Bunker topped the Neilson Ratings. A cup of coffeee cost 30 cents.

Two old foes, Rene Levesque and Pierre Trudeau, squared off against each other in the political battle of the century in this country. Canadians held their breath as Quebekers voted in the Referendum and the future of the nation hung in the balance. Then suddenly, it was over. Quebec was in. Trudeau was out. And a man from High River, Alberta became Prime Minister of Canada.

Figure 2. The 60's - "Utilization"

- Top diameter drops to 8 inches (coast)

- Eustace Smith dies

- New pulp mills flourish

- TFLs in disfavour - introduction of quota system

- Production - 45 million cubic metres

- 17.8 million seedlings

\section{The 70's - Reforestation}

In forestry, as elsewhere in society, the changes initiated in the sixties reverberated in the 70's. The environmental movement comes of age. The future of a remote area on the west coast of Vancouver Island - called the Nitnat Triangle - makes the headlines and becomes a major election issue in 1972. Battlelines were indeed being drawn.

It was time for another review to sort out where we were going. A new Royal Commissioner, Peter Pearse, was appointed to look at the industry. His work was precipitated by a wide-spread desire to assess where we were relative to the many evident changes surrounding forestry - such as environmental issues, the allocation of the resource, the future of the small businessman and the question of new entrants into forestry operations. His report of 1975 and the subsequent new Forest Act of 1978 was to be the blueprint for the next decade or so. Section 88 of the new Act provides funds for forestry and the first budget indicated $\$ 25$ million for reforestation and roads.

Forestry in British Columbia took a "great leap forward" in the 70's. Reforestation was the name of the game and there was a lot of optimism about how good we could become at playing it. By 1975 , we were planting over 60 million seedlings a year, with the interior planting even more than the coast. Pine and spruce surpass Douglas-fir in the number of seedlings planted.

The highlight of my career occurred in this decade when I became the first Chief Forester in the forest industry to become a Vice President of Forestry. At last the role of forestry was being recognized by senior management within the industry.

Figure 3. The 70 's - "Reforestation"

- "Great Leap Forward"

-60 million seedlings

- forestry/senior management concerned with environmental issues

- Pearse Commission

- new Forest Act

- Section 88

- "Boom time"

- growth in interior industry

- new plants/investment

- Production - from 50 to 75 million

Utilization: 6 inch (coast)

4 inch (interior)

The industry itself was, for most of the decade, in a period of unparalleled growth and prosperity. The growth in lumber production in the interior of the province, where the more even terrain and narrower mix of species created opportunities for mechanized logging and high volume output, was particularly dramatic. By the end of the decade, close to $70 \%$ of the softwood lumber produced in the province was coming from the interior.

Spurred on by the predictions of high market demand as the post-war baby boom reached consuming age, the forest products business was booming. New mills or plant upgradings were being announced each year and forestry staffs were expanding. By the mid-seventies the AAC had grown to 50 million $\mathrm{m}^{3}$. By the end of the seventies it had mushroomed close to its current level of 75. Utilization policy called for a 6-inch top on coastal old growth and a 4-inch top in the interior. 


\section{The 80's - Silviculture}

Which brings us to the 80 's, yet another period of tremendous change. The age of the computer. The Iranian hostages. Conservatism emerges as a revitalized force in the political arena. Ronald Reagan becomes the most popular President the United States has ever had.

Then the recession and the most serious economic upheaval since the Depression. A weary population tunes in a Hollywood soap opera called Dynasty on TV and rents videos about Star Wars adventures in outer space to help them forget their problems. Spiked hair is in. Preferably purple. The Punk Rockers make the Hippies and Flower Children of the 60's look normal in comparison. Baby boomers turn into Yuppies and start having babies of their own.

In contrast to the young person of the 50's, the typical young 80 's person ready to enter the working world is: One: probably female. Two: sure of her beliefs and values (one of which is that men work best in non-stressful, non-competitive activities like ... managing seed orchards, for example.) And Three: confident of her ability to be successful, but somewhat unsure as to whether she'll be able to make it through the male network to the top. She likely has an outwardly liberated spouse - who still depends on her to do much of the work around the house - has only one child and sees herself as an unflappable parent like, say, Kate or Ally.

A cup of coffee costs anywhere from 50 cents to a dollar. depending on where you buy it.

In the countdown to the 90's the political pendulum is showing signs of swinging back. The conservative tide slows to a trickle as the governments of both Ronald Reagan and Brian Mulroney are rocked by allegations of scandal and incompetence.

And in BC forestry - by all rights, the groundwork done in the seventies should have made the eighties the decade of silviculture - of enhanced forest management. But the economic dislocation of / 82 through to / 84 shattered all our hopes.

Our ambitious plans were put "on hold". Forest funds were raided to pay for other much-needed government services. Sales plummeted. Our books wouldn't balance. Both industry and government went into a painful period of reassessment. Production slumped, over 20000 jobs were eliminated, stumpages were reduced to minimums. We were dubbed a "sunset industry". To survive, the industry drastically cuts costs. All energies focus on the need to obtain higher value from labour, capital and equipment.

The going got tough and the tough got going. The $\mathrm{BC}$ forest sector responds to the challenge of change. By the mideighties, productivity levels have increased dramatically. Reaping the benefits of some of the investments made during the heady days of the late seventies, lumber production per employee rises over $30 \%$.

But in some respects, we become victims of our own success. Suddenly we're in trouble again with our increasingly protectionist neighbours to the south. Canadian politicians move to head off what they fear will be the imposition of a U.S. tariff on Canadian lumber by imposing a domestic tax on lumber exports to the U.S. The Canada/US lumber dispute raises serious questions about future access for our products to a range of markets.
The coastal industry attempts to restructure by moving into higher valued products. In forestry, "value" replaced "volume" as a decision criteria. The AAC hangs in there at about 75 million $\mathrm{m}^{3}$. We've reached the limit - or have we? I'll have more to say about that later. But it is clear that future growth in the cut will require substantial investment in basic and intensive forestry.

Better forestry and increased cuts are linked to longer term tenures. TFLs come back into vogue. Hearings are held for four applications in the interior and the interest is tremendous. Forest tenures with terms of 15 years are replacing Timber Sale Harvesting Licensses. Land use questions become increasingly complex and increasingly vital. Controversial proposals to remove forest land for single use dominate the media and native land claims add a new dimension to the debate.

Despite the setback during the early part of the decade, if we go hard at it from here on the ' 80 's could still qualify as the decade of silviculture. Over $50 \%$ of logged areas are being planted. The goal is to move that up to 75 . We planted 100 million seedlings in 1985 and are aiming for 200 million by the end of the decade - with all native species being represented. Over $90 \%$ of seedlings being planted are from containers.

After some levelling out, Section 88 allotment for forestry projects in 1984 was increased to $\$ 48.4$ million. Concern about the backlog - particularly in the interior - thrusts the forest community into a high stakes lobbying game in both Victoria and Ottawa for funds to address the problem. The result: the federal government enters forestry financing with a joint agreement with the province for a 5-year $\$ 300$ million backlog reforestation program.

Figure 4. The 80 's - "Silviculture'

- Recession

- forestry plans "on hold"

- Industry restructures - 20000 fewer jobs

- "value" vs. "volume"

- Restrictions on exports to U.S - export tax

- TFLs back in vogue

- 200 million seedlings - some funding for intensive

- \$300 million for backlog

My purpose in taking you on this quick trip through the decades is to demonstrate that in forestry - as in society as a whole - time moves on, we respond to changes and still the issues develop to challenge us. If history teaches us anything, it is that changes will come and somehow we survive. The real challenge is how well we adapt. How much are we able to shape the future of forestry to optimize both the resource and its use.

In the final analysis, we would do well to remember that in forestry - as in the rest of society - the winds of change never stop blowing. Even when a new order arises it turns out just to be a transitory phase; a temporary point of stability from which to gaze nervously into the next "new future". 


\section{What Lies Ahead?}

So much for where we've come from. I'd now like to turn my attention to the current state of forestry in B.C. Where are we today and what lies ahead? Unfortunately, the answer to that question probably depends a lot on who is being asked.

As you know, some of our politicians think our forests are a "silvicultural slum". I don't happen to agree. As a matter of fact, I take great exception to that statement. But then, I'm biased, I've spent a lifetime working with the trees of this province. Politics is, of course, the art of instant answers, regardless of the issue. But I must confess I look forward to the day when a politician answers a supplementary question by saying, "I have already told you more than I know."

To elevate our thinking about the current situation in our forests we should try to be as objective as possible. So let's for a moment assume that the $\mathrm{BC}$ forest resource was just discovered today. No past for comparison, just an opportunity for the future.

I dare say that we could even get the politicians agreeing that in its present condition the forest resource in this province is a fantastic asset by any standard of measure! On closer inspection, we would see areas where it should be improved, but our attention would first be caught by the overall excellence of the resource - something that seems to get overlooked a lot these days.

Remember, we are talking about a new-found resource at the moment. There are no fingers to be pointed at the past, only opportunities to be identified where we can profitably address forest management efforts for the future. As managers, we would likely compare our new-found assets to those in other parts of Canada and to those of competing producers around the world. And that would get us even more excited about what we've found. Then we would make some basic decisions about the most desirable kinds of industrial structures, the most efficient administrative arrangements and the best programs for managing the resource in the longterm provincial interest. Those decisions would be in keeping with the nature of the resource and the social and economic needs of the province.

Of course, life isn't quite that easy. There are significant constraints on how we can adjust to change in the forest sector. A large industry is already in place. So are the various economic sectors and communities that depend on it. And while administrative processes are not written in stone, a tenure system with legal commitments is also already established.

In addition, the very fact that our condition is relatively good compared with other regions or countries can, at times, work against the type of long-term planning required. Political and, to some degree, corporate decisions can be postponed with the rationale that we can continue to be comparatively better and that there will be time enough for those necessary actions "somewhere down the road". And on the "minus" side of the ledger, there are a bunch of public attitudes which, rightly or wrongly, reflect long standing prejudices and expectations regarding forestry. Unfortunately, one of them is that British Columbians have a long history of being well served by the resource at relatively little cost.

But on the "plus" side of the ledger, we have:

- a good Forest Act,

- capable professionals and workforce,

- a good mixture of size of companies,
- a good blend of up-to-date plants,

- a forest land base occupying a significant portion of the total land base, and

- at least 25 years of old growth timber remaining.

\section{Let's count our blessings!}

I think an objective report card on this province's forestry performance to date would give us good marks for basic forestry, poor marks for intensive - and a severe lecture on the need to make decisions now for the future.

Our experience here in British Columbia is typical of a historic and demonstrated progression in natural resource use throughout the world.

The first stage is exploitation of the resource, exploitation to provide the impetus for economic growth. Monies from the forest built the schools, hospitals and highways of this province - and for that matter, continue to support them. Then when the question of scarcity enters the equation - as it did in B.C. with the Sloan Commission - the second stage in the progression begins and policies which seek to control use and sustain the benefits created by the resource are developed. With the realization that there are no more frontiers comes the impetus to define the forest land base, to introduce controls, utilizations standards and reforestation and protection programs. Finally, the third phase - marks the application of new concepts and modern technology to enhanced management of forest resources and ecosystems. It occurs when the land has been allocated, the funds to use and manage it have been established and the fundamental rules have been set to ensure that it will continue to maintain a flow of goods and services.

I think we reached the third phase of that progression some time ago in this province but, because of economic conditions during the past few years, our performance has been a bit shaky. We do, however, still have the opportunity to make up for some of that lost time.

The AAC curve tells the story and it's not a very complicated one - although we seem to have a talent for making it appear that way.

This is where we are. This is where we'll go at the current rate of investment in forestry, and if land use pressures continue to result in the removal of land from the forest land base. This is where we could "hang in" with more investment in basic and intensive. And this is where we could go with high levels of investment in intensive.

Land alienation provides the downward pressure. And forestry - basic and intensive - are the main weapons we have to resist that decline with.

To return to the allegation of a "silvicultural slum" sometimes I think we Canadians have a terrible inferiority complex. We have some of the best forests in the world in this province! And we have some of the best people in the world when it comes to managing and using that resource! Sure there's more to be done. There'll always be more to do. But why can't we take some pride in what we have at the moment? Why do we always seem to be out there beating our chests and telling the rest of the world what a crummy job we're doing?

Canadian foresters must be the only people in the world that set standards for their performance - change those 
Figure 5. Annual Allowable Cut - B.C.

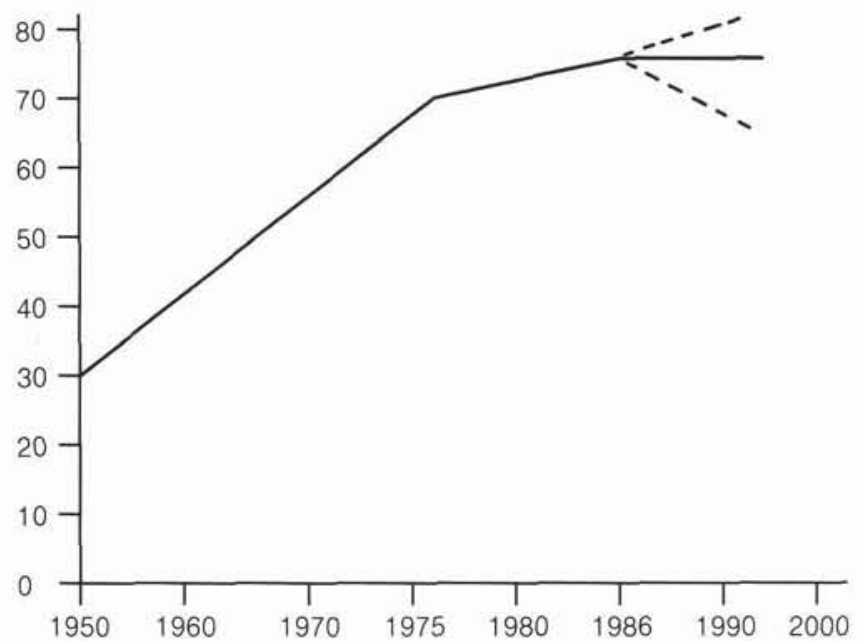

standards to reflect changing times and technologies - and then judge their performance in earlier eras against the standards of today. No wonder we always come out of that process looking as if we goofed!

But do you hear doctors blaming themselves for all the deaths that occurred before antibiotics were invented? Or dentists blaming themselves for cavities before fluoride was invented? It's ludicrous. Yet we foresters do it to ourselves all the time. And we no doubt pay a price for it. How can we really blame the public - and even the politicians - for doubting our ability to perform when at times we sometimes don't even seem to believe it ourselves. I wonder when the foresters of this province are going to really believe in the power of intensive forestry!

Problem areas? Yes. We have a number of them. Silvicultural slum? No way.

If you're thinking I have an axe to grind on this one, some turf to protect - you're absolutely right. I've worked long and hard, and I know many others who have worked longer and harder to achieve what we have to date in forestry in this province. And it is a significant achievement, one we can be proud of not complacent about - but proud of. The allegation of a slum hurts. It's not fair. It's not accurate. But I for one am willing to take my lumps - to grin and bear it - if it will provide the motivation and commitment necessary to move us from loss to gain on this AAC chart.

Sometimes you need a "catalyst" to get things happening. I wince every time I hear it, but maybe fear of a "silvicultural slum" is the kind of catalyst we need now in B.C. to get the commitment necessary to make us full and vigorous participants in the all-important Third Phase of resource use.

Which brings me to the second part of this presentation. Don't worry, it's a short part.

I made some reference at the beginning of these remarks sharing with you the story of an incredible imaginary phone call I received last Sunday from Victoria. Well, I was just finishing off my coffee when I picked up the line and who should be on the other end but ... Bill Vander Zalm. He told me he was in the business of fulfilling people's fantasies - and after a lifetime in the forestry profession, the "Powers that Be" had decided that I was entitled to have one of mine come true: at least for one day! You can imagine the number of things that went through my mind. One doesn't live for the amount of time
I have on this planet without collecting the odd fantasy. I'll be honest, it was a tough choice. But it really didn't take me too long to decide. In the end, the forester in me won out. To my wife's total and utter disbelief, I told Mr. Vander Zalm that my ultimate fantasy was to be "Minister of Forests" for the province of British Columbia!

He asked me if I was sure that was what I wanted. I told him it was.

Then he sort of had a "fatherly chat" with me and warned me that contrary to appearances, it's not easy to be a politician. People tend to have unrealistic expectations of their politicians.

They expect them to be:

- decisive without being authoritarian,

- confident without being conceited.

- innovative without being radical

- tireless without being tiresome,

- hard-nosed without being unreasonable,

- expeditious without being hasty,

- generous without being naive, and to be good without being perfect.

I assured him that he didn't have anything to worry about on the "perfect" front as far as I was concerned. But imperfections and all, I did have a few things I'd like to get done and being Minister might help a whole lot. So, he said that was "Fan-tas-tic" - and I guess that must have been the magic word because suddenly I was sitting behind the Minister's desk in Victoria. And l'd like to tell you what l'd do, given the change to sit behind that desk.

\section{If I Were Minister of Forests}

As I would only have a day, l'd get down to work right away. The first thing l'd do would be to write out my objectives. I'd probably start with 10 - including a lot of high-flown words about proper management of the resource in the peoples' interest etc. etc. - but with a bit of work l'd reduce it down to one sentence that said it all. Those of you who know me and know that I have spent the better part of my career crowing about the power of intensive forestry won't be surprised to learn that my prime objective as Minister of Forests would be to move this curve up - to increase fibre production - to grow trees.

I wouldn't want to simply do what was necessary to maintain the current cut, l'd want to increase it. I am convinced that the resource has the capability and so do the people looking after it. But I wouldn't try to move it up at any cost. It would have to be at a cost in keeping with the economic reality of the time. I'd need a plan, a good one, with follow-up. I wouldn't have time for another Royal Commission, nor do I think we really need another one. Lots of studies have been done.

I'd call in my staff and we'd try to incorporate the best of all of the existing plans. It would probably be about a 40 -year plan.

First, we would concentrate on inventories, including an expanded growth and yield program, both for managed and unmanaged stands. After all, our future is tied to the second growth forests, and the growth of stands is paramount to the stability of employment and communities.

My "master plan" would also encompass basic programs for a reforestation commitment of, say, 300 million seedlings a year, and an intensive program of spacing, fertilization and 
genetics on all appropriate stands. The bulk of my expenditure - about $80 \%$ - would go here. Of course, tied in with this program would be a budget for research, education and public relations - which would probably represent around $10 \%$ of the total. The entire cost of my budget would be around $\$ 5$ per $\mathrm{m}^{3}$ of cut, which is my investment for the future. The Swedes spend about \$7-\$8 per $\mathrm{m}^{3}$ and our current investment is about $\$ 2$ per cubic metre.

Once I had my plan - we'd spend a bit of time - a couple of hours at least - talking to everybody about it. I know how those industry guys would holler if they didn't get consulted. I'd tell the industry that l'd get the province to cover the costs of basic but they'd have to pay for intensive. In return, l'd be prepared to give them incentives that would encourage the highest level of management possible under current economic circumstances. Perhaps longer term tenures. Perhaps some other type of offset such as $25 \%$ of minimum rate for the intensive "lift" portion.

Next comes the tough part. l'd have to sell the plan. l'd have to sell it to the people, the Premier, my Cabinet colleagues and - probably the toughest audience of all - the Treasury Board. And my counterparts in industry would have some selling to do too. They'd have to sell their companies on the benefits of large scale investments in intensive forestry.

It has been one of the enduring frustrations of my career that I and, as far as I know, none of my colleagues, have ever been completely successful in our effors to make a hard economic case for investment in forestry. Some have suggested that the case can't be made without increased prices for the resource.

Maybe so. But I wouldn't be able to wait for rising world prices for forest products to stimulate investment. And as for getting more money out of the industry at the resource level the tax on our softwood exports to the U.S. is already bringing in more than an additional $\$ 1$ million a day to the provincial treasury. Those dollars are already being raised.

\section{The money is here! And we need it for forestry projects!}

To prepare for the biggest sales job of my career l'd go out to the universities and l'd look for the best and brightest among students and faculty alike in a number of different areas including forestry, biology, economics, law, political science, education - maybe even philosophy. Then l'd go to the industry and get their best and brightest as well. And finally l'd go to the "Old Forest Crony" network and pull in some of the dedicated, retired pioneers who taught me much of what I know. l'd take them all up to the convention centre at Whistler Mountain. I'd tell them all to leave their egos at the door and l'd push them inside and lock it. And I wouldn't let them out until they'd developed solid rationales that would justify investment in forestry in a technical and scientific sense, in an economic sense, in a political sense, and in an emotional sense.

Then I'd wait. And I don't think l'd have to wait very long. I hope not - because l'd only have a day. Once I got those rationales in my hands l'd descend from Whistler the way Moses came down from Mt. Sinai. The Strait of Georgia would part! And l'd walk to Victoria to present my case.

l'd marshal my arguments and my troops and launch an onslaught on Victoria the likes of which haven't been seen since Empress Hotel put on a free tea. l'd tell the Treasury Board and the Cabinet that every cent of that new $\$ 400$-million tax should go into a Forest Heritage Fund. I'd admit that I couldn't spend it all on forestry today in a cost effective manner. But with a plan, over time, l'd convince them that earmarking that money for forestry could be the best investment this province ever made.

And when the going got tough, l'd pull out my ace in the hole - my secret weapon.

l'd go round the bean counters and the politicians to the people of this province. Armed with my new rationales, l'd convince them.

And I'll bet you that it wouldn't be all that tough a job. The people of this province already believe our forests are the best thing this province has going for it. I suspect they want to believe that forestry is a good investment. All they need is a bit of proof - a bit of confidence in the ability of the forest community to deliver the goods. I wouldn't ask them to choose between a heart machine and a tree. l'd ask them to choose between one heart machine or enough heart machines to last for generations to come ... between the cold comfort of a shortterm fix or a sustainable future based on the vitality of a worldclass industry.

\section{Because in reality, that's the choice before us today.}

l'd get the public on my side and sure as night follows day, I'd get the commitment I need for my plan from the politicians and the technocrats. That's the great thing about democracy.

So there you are. My fantasy is that we can have stability of cut, of employment, of profitability, of revenue to the Crown and we can see this industry continue as the economic mainstay of our province. It's time to move beyond the myths. We're not a sunset industry. We're not a dinosaur. We haven't grossly mismanaged the resource or the environment. Sustained yield is alive and well. In fact, I do not believe we have yet reached the limits to growth.

However, I don't want to leave you with too-rosey a picture. There are some clouds on the horizon. Just as we need to keep some perspective on our relationship to the rest of our society, so too we must constantly keep in mind the international context in which this industry must operate. As we saw in the early 80 's, there isn't a great deal we can do when international factors turn against us. We may be a big fish in this pond but we're a barnacle on the back of the whale in some areas.

There isn't a great deal we can do about fluctuations in international currency values, about protectionism, about slower growth in world demand, about new producers entering traditional markets and domestic production replacing imports. Yet each of these factors can have just as profound an impact on our industry as any of the challenges facing us on the resource side.

All the more reason then to seize the initiative and make sure we're in fighting form in those areas - like forestry where we can exercise some control! Because we're going to need to be in "top shape" on the supply side to respond to the shifts and complex running plays the market side is going to be demanding of us.

This is a good industry - a proud industry - and we do not have to hide our heads in shame. It is an excellent industry for employment, one with a good future, one that has many challenges and one that is highly rewarding in the long run.

I have enjoyed every minute l've been a part of it. 